・爪圧迫テストの異常は少なく, 握力, 手指筋力, タッ ピングの異常は差異をみとめなかった。

3）手指蒼白・しびれの発症および異常検查所見は， 泊動鋸を使用する時間，連絖使用時間との関係が強くみ とめられた。すなわち，自動鋸を使用している集材手と 伐材手のあいだには著明な差がみられた。この外科か $ら ，$ 温暖な地方でも年間を通じて自動鋸を使用復兮作業
内容の影響を注目すべきである。

4) 数地区に打いて左足趾。足踓（1例は両足）に蒼 白があらわれていた。これらの作業者は，傾斜が強いた め左足を自動鋸の一部に直接かけた姿勢で伐木すること が多かったといっている。この蒼白な冷却負荷でも此軧 的容易に誘発された。

5）自動鋸使用作業中（7 分），拉よび休㮩中（6 分） の手指, 手背, 手掌の皮膚温, 前後の把多多党湘定乙 た。その変動は季節, 外気温に左右されるか，蒼白をみ とめる手指はそうでない指に比して作業中の皮膚温低下

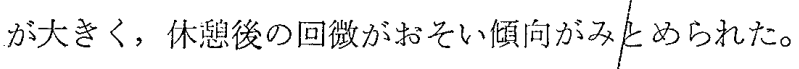

これらの所見から温暖な地方に扔る振動病症状の問 題点についてのベたい。

\section{公}

\section{害}<smiles>C1C[As]1</smiles>

\title{
115. 南陽町における原因不明の刺激性ガスの疫学的調
} 查

\section{上野碩夫，吉崎和子（山口大医公衛）}

石油化学コンビナートの街山口県南陽町の工業地率 は, 西側工場群（ソーダ, 石油化学等）と東側工場群（ソ 一ダ，製鋼）からなっていて，両工場群の中から原因不 明の刺激性がスが発生し，工場周辺の住民からの苦情が 続出し，その対策に苦慮した。

そこで，刺激性ガスの本態究明の手がかりを求めるた めに，被害地域全世带を対象としたアンケート調相（対 象世帯数630，回収率77\%) を行ない，つぎの事項を認 めた。

1）原因不明のガス刺激を感じたことのある者の頻度 は，西側工場群に近接した地域ほよ゙多かった。

2)刺激を感じた風向は，各地域とも西側工場群の方 向と一致していた。

3）刺激を感ずるときの天候は，譬天で無風または弱 、風のときに多かった。

4）刺激を感じた時到は，午前中（40\%）执よび朝

(31\%) が多く，昼（9\%）には少なかった。

5）ガスの刺激の種類は，眼の刺激 $(78 \%)$ が最も多 く，何之もいえない臭 $(44 \%)$ ，咽陸の刺激 (42\%)，嗔 痛 $(36 \%)$ ，吐さ気 $(29 \%)$ ，甘ずっぱい臭 $(27 \%)$ ，食 欲不振 $(23 \%)$ (以下略) の椇であった。

6）訴克頻度が，工場からの距離に比例して減少して いるものだけを列挙してみると，それらの訴壳を共通的 に支配している厚因物啠が何であるかが推測された。か くして，厚因物啠之考えられるものを列挙してみると， 西側工場群の生産工程中に発生する物質が主な原因物質 であることが推測されるにいたった。

7）アンケート調查とは別個に，町当局が任命した公 害モニター（6名）の報告資料からも，上述の知見を裏 付できる成績がえられた。

8）かくして，原因不明とされた刺激性ガスの本態が 推定されるにいたった。

\section{6. 徳山市における原因不明の刺激性ガスの疫学的調 查}

\section{北川良雄，吉崎和子（山口大医公衛）}

石油化学コンビナートの街では複雑多岐にわたる刺激 性ガスが発生し，しか女，刺激性ガスはその発生源が多 く, 各種のガスが混在しているので, そ本の態や発生源 を明らかにすることは容易ならざる問題である。しかも 市民の苦情は深刻である。

この問題に対処するために，私共は炤和 42 年 7 月，石 油コンビナートの街, 徳山肪に拀いて, 厚因不明の刺激 性ガス追求の手がかりを克るために，工場周辺地区民 (380世带) を対象に，アンケート（回取率69\%) による 疫学的調查を行ない，刺激性ガス笲明の手がかりを光る ことができた。石油化学コンビナートの街では, 同様類 似の苦情解決に苦慮されている例が多い亡思料されるの で, 調查方法論的にその概要をのべて, 参考に供した w。

本調查方法は, (1)地区別, (2)風向, 風速別, (3)天候 別，(4)時刻別，(3)刺激の種類別にみメた刺激の頻度。(6)所 在する工場の原料, 中間産物, 製品, 製造工程などを総 合的に検討して，刺激性ガスを発生している工場名と原 因物筫を推測した。

(1)执よび(2)により発生源の所在方位を推定し, (3)お び(4)では刺激性ガスが工場から一次的に排出または漏出 したものか，あるいは二次的に大陽光により光化学反応 の結果生成されたものかぞうかルついての検討を試夕， 
(5)地区別にみた刺激の種類から厚因物質を推定し，最後 に(6)当該地区工場の厚料，中間産物，製品などから放出 される物質との関係を追求して刺激性ガスの本態究明に 資した。

かくして，本事例は德山市のN合成ゴム工場から一次 的に放出されたブタデェン，ブタン，スチレンなどを主 体としたものであると推定されるにいたった。

\section{7. 呼吸器系における $\mathrm{NO}_{2}$ の撖取}

山口 裕, 小西美智子 (昭大医衛生) 石川清文 (昭大医公衛) 市岡正弘，北 博正（医雪大医衛生）

水にとけやすい $\mathrm{SO}_{2}$ が，大部分上部気道で椇取され るのにたいして，水にとけにくい $\mathrm{NO}_{2}$ は，上部父道で はわずか江掑取されるのみで，大部分が脯の深部まで 到達するということが，一般的な考光となっている。 $\mathrm{SO}_{2}$ の呼吸器系に和ける摄取については, すで検討さ れているが，演者らは， $\mathrm{NO}_{2}$ の呼吸器系に括ける摂取 そついて娭討を試みた。

まず, $\mathrm{NO}_{2}$ の呼吸器系汇特ける摂取率を测定する方法 として，つぎのよらな装置を考えた。すなから，空気で $5 \mathrm{ppm}$ 前後にうすめられ，マイラーバッグに貯藏された $\mathrm{NO}_{2}$ は，ポリエチレン製ノーズピース（特製）で吸入 され，呼気はマウスピースを通して集如られるが，大流 量で出てくる呼気は，一度別のマイラーバッグに集め， それをあらためて規定の小流量で，バブラー中の Salzman 試薬に吸収させながら，呼気量をも計量する。呼 気を直接バッグ内に集めると，その中で結露するので， そ礼を防ぐため，マウスピースとバッグとの間水冷式 コンデンサー（特製）を和いて，呼気学除湿する。コン デンサー内の結露中に $\mathrm{NO}_{2}$ がふくをれているので，そ の内壁をスプレーで洗った洗液（Salzman 試薬）とあ わせ, さらにバッグ内の $\mathrm{NO}_{2}$ 呼気を吸収させるバブラ 一の Salzman 試暞に加光て比色定量し, 総量を呼気中 飞出現する $\mathrm{NO}_{2}$ 量とした。

このようにして捕集定量された呼気中の $\mathrm{NO}_{2}$ と, 吸 気中の $\mathrm{NO}_{2}$ 濃度から求められる $\mathrm{NO}_{2}$ 量から, 呼気中の 濃度から求められる $\mathrm{NO}_{2}$ 量から, 四吸器系飞打ける $\mathrm{NO}_{2}$ の摂取率が求められるが，5 ppm 程度の $\mathrm{NO}_{2}$ の吸

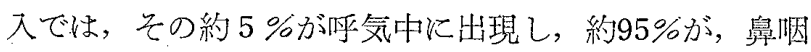
腔一気管一肺の経路で摂取されるものとみられる。
118. ディーゼル車庫及び長大トンネル内でディーゼル 動車㩑気ガスが作業者に及ほす影響

$$
\text { 松藤 元, 山崎和秀（鉄道学研） }
$$

国鉄の動力近代化によって，蒸気機関車は減少し，こ れにかわって電車，ディーゼル動車が多くの線区にわた って走るようになった。とくにディ一ゼル動車は運転效 率からいってき和めて有用であり, 現在 5,310 両が使用 されている。

血煙化対策として登場したディーゼル動車ではある が，その排気ガスの毒性は無視できないものがあり，と くに，これらの車雨索整備する車庫や，ディーゼル動車 が通る長大トンネル内などで働く作業者に排気ガスが影 響を和上ぼす恐れが增大した。

そこで，車両基地 4 籄所の車庫（尾久，金沢，秋田， 青森）と，長大トンネル 5 不所（欽明路, 物見, 冷水, 釈迦岳，士修の各トンネル）の環境調查と，そこで作業 する作慈者の自覚症状調查叔よび呼吸機能検査を行なっ た。

排気ガス湛度を $\mathrm{NO}_{2}$ と $\mathrm{SO}_{2}$ についてみると，車庫内 では $\mathrm{NO}_{2}$ 0.03〜3. $04 \mathrm{ppm}, \mathrm{SO}_{2} 0 \sim 2.85 \mathrm{ppm}$ ，トンネル 内では $\mathrm{NO}_{2}$ 0. 03〜2. $46 \mathrm{ppm}, \mathrm{SO}_{2}$ 0 2.80 ppmである が，トンネル内で $\mathrm{NO}+\mathrm{NO}_{2}$ の橓間值 $18.15 \mathrm{ppm}$ を測 定した。

作業者の自覚症状を問診によって調查したところで は, 排気ガス搌度の比校的高い䇢所の作業者侅, 痰, 息苦しい, 感冒, 咽頭の刺激感なぞ排気ガスの影響が考 えられる症状が他の箇所と比校して高率にみられた。

呼吸機能唡查としてスパイログラム, ピークフロ一值 をしらべたが，排気がスの影響と考学られる機能低下は あまり著明ではなく，か劣って哭煙の影響のほらが大き いようであった。

\section{9. 若干の悪臭物啠に対する嗅覚闇值}

松下秀鶴, 有藤平八郎, 鈴木康友, 左右田礼典 (学衛研)

覀臭・公害の発生頻度は近年急速に增大しつつ亦る。 筆者らは琹臭公害対策の一つの基礎資料をるとめる目的 で若干の悪臭物質にたいする嗅覚閾值をもとめた。

咱覚閾值は臭気瓶をもらいる溶液希釈法によった。悪 臭物質としては，昭和 41 年度にメルカプタン類を測定し たので，本年塺はアミン類17種，アルコール類13種をも ちいた。被験者は成人女子 15 名である。嗅覚閾值は測定 